\title{
Interest Rates and Inflation as Determining Factors of Saving in Central Sulawesi Banks
}

\author{
Andi Herman Jaya, Tasrina Sari Tolla, Ahmad Syatir, Anwar Nasruddin, Novita Sari, Haerul Anam* \\ Department of Economics \& Development Studies, Faculty of Economics Tadulako University, Indonesia
}

Received January 22, 2021; Revised June 15; Accepted July 19, 2021

\section{Cite This Paper in the following Citation Styles}

(a): [1] Andi Herman Jaya, Tasrina Sari Tolla, Ahmad Syatir, Anwar Nasruddin, Novita Sari, Haerul Anam, "Interest Rates and Inflation as Determining Factors of Saving in Central Sulawesi Banks, "Universal Journal of Accounting and Finance, Vol. 9, No. 4, pp. 531-541, 2021. DOI: 10.13189/ujaf.2021.090401.

(b): Andi Herman Jaya, Tasrina Sari Tolla, Ahmad Syatir, Anwar Nasruddin, Novita Sari, Haerul Anam (2021). Interest Rates and Inflation as Determining Factors of Saving in Central Sulawesi Banks. Universal Journal of Accounting and Finance, 9(4), 531-541. DOI: 10.13189/ujaf.2021.090401.

Copyright $\odot 2021$ by authors, all rights reserved. Authors agree that this article remains permanently open access under the terms of the Creative Commons Attribution License 4.0 International License

\begin{abstract}
This study aims to analyze the effect of the Central Bank, which is in Indonesia presented by Bank Indonesia (BI) Rate and inflation rate on the savings rate at commercial banks in Central Sulawesi by using the analysis tools of autoregressive conditional heteroscedasticity $(\mathrm{ARCH})$ and generalized autoregressive conditional heteroscedasticity (GARCH). The results of the analysis show that the BI Rate and inflation have significant effects on saving rate at commercial banks in Central Sulawesi. The importance of being a source of investment funds to support development activities can be a consideration for the government to formulate a policy for allocating investment from these savings funds for productive sectors. Practically, it is hoped that the distribution of savings through investment activities can encourage economic growth and increase economic development in Central Sulawesi.
\end{abstract}

Keywords BI Rate, Inflation, Savings, ARCH, GARCH

\section{Introduction}

Commercial Bank has a very important role in moving the wheels of Indonesian economy, because more than $95 \%$ of the third-party fund of national banking is in Commercial Banks. The amount of commercial bank savings in Central Sulawesi Province, in 2010 was $3,933.87$ billion rupiah. In 2012, third party funds for commercial banks in Central Sulawesi Province amounted to $5,719.47$ billion rupiah. In 2013, third party funds for commercial banks in Central Sulawesi Province amounted to $6,587.21$ billion rupiah, and in 2014 it was 7,223.90 billion rupiah. This shows that the savings rate at commercial banks in Central Sulawesi Province has increased from year to year [1].

BI Rate or the interest rate of Bank Indonesia is the basis for interest rates on loans and deposits for banks and/or financial institutions throughout Indonesia. Changes in the Central Bank rate, which is in Indonesia presented by Bank Indonesia (hereinafter BI Rate) indicate Bank Indonesia's assessment of future inflation forecasts against the inflation target set. The movement of the BI Rate in 2007 was $6.16 \%$, in 2008 it increased by $8.47 \%$, an increase in the BI Rate, resulting in an increase in loan interest rates, which depleted economic growth. Economic conditions in 2009 pointed to a positive trend as reflected in the determination of the BI Rate at $7.16 \%$. In 2010, the BI Rate was set back to a positive trend with a reduction in the BI Rate setting to $6.06 \%$ [2]. The rise and fall of the BI Rate interest rate will affect growth in a country.

The development of the inflation rate in Central Sulawesi in 2010-2014 experienced fluctuating movements. In 2010 the inflation rate in the province of Central Sulawesi was $6.40 \%$. In 2012 the inflation rate decreased to $5.87 \%$. In 2013 the inflation rate has increased to $7.57 \%$, and for 2014 the inflation rate has increased again by $8.85 \%$ [2]. 
Inflation also has an important influence on the level of third-party funds or funds originating from the public, one of which is in the form of savings at commercial banks, so that if there is an increase in inflation, Bank Indonesia as the monetary authority will issue a policy by lowering the interest rate to overcome inflation [3-5]. Inflation that occurs at a level that is too high (prices jumped sharply) will be felt by all levels of society, especially in the middle to lower class. A country will experience inflationary pressure (investment inflation) when investment spending increases in a state of low interest rates. People or entrepreneurs are less interested in saving or saving their money in a bank, they are more likely to invest their money/capital, so that inflation has an effect on people's savings.

The background of the problems described is based on the description above, so the problems formulated by the researchers in this study are how the effect of BI interest rates, and inflation simultaneously and partially on savings in Indonesian Commercial Bank? Based on the problem above, the researchers have the objectives to be achieved in this study, namely to determine the effect of $\mathrm{BI}$ interest rate and inflation simultaneously and partially on savings in Indonesian commercial bank.

\section{Literature Review}

Helvira [6] showed that Gross Domestic Regional Product per capita, conventional banks interest rate, inflation simultaneously influence Islamic banks deposit in West Borneo. Partially, Capita Gross Domestic Regional product has positive influence; convention banks interest rate has negative influence, while inflation does not have significant influence towards Islamic banks deposit in West Borneo. Nurulhidayat [7] showed that inflation has a negative and insignificant effect on the deposit amount, interest rates have a negative and significant effect on the amount of deposits, Finance to Deposit Ratio has a negative and insignificant effect on the amount of deposits and profit sharing rate has a positive and significant effect on the amount of deposits.

Lengkong et al., [8] showed that GRDP has an influence on the savings rate of the people of North Sulawesi, while Inflation and Interest Rates together do not affect the level of community savings in North Sulawesi. Klasjok et al., [9] showed that the interest rate has a negative but significant effect on the savings in West Papua, PDRB has a positive but significant effect on the savings of the people in West Papua while the inflation rate has a negative but significant effect on the saving of society. Based on the literature, the hypotheses proposed in this study are following:

H1. There is a positive and significant effect of BI Interest Rate on the Savings Rate at Commercial Banks in Central Sulawesi Indonesia.

H2. There is a positive and significant effect of Inflation on the Savings Rate at Commercial Banks in Central Sulawesi Indonesia

\section{Research Methods}

The type of research used in this research is descriptive type with an associative approach. As for the purpose of looking at the relationship between the BI Rate and Inflation Rate of Savings at Commercial Banks in Central Sulawesi for the period 2005 to 2014. In this study the dependent variable was the Savings Rate at Commercial Banks (Y), while the independent variable was BI Interest Rate (X1) and Inflation (X2). Sources of data come from Bank Indonesia [1] and BPS-Statistics Indonesia [2].

The methods used are Autoregressive Conditional Heteroscedasticity (ARCH) and Generalized Autoregressive Conditional Heteroscedasticity (GARCH). To explain how the ARCH and GARCH models are formed, it is necessary to use a multiple regression model as follows. The general form of the multiple regression equation can be formulated:

$$
\mathrm{Y}=\beta 0+\beta 1 \mathrm{X} 1+\beta 2 \mathrm{X} 2+\ldots .+\beta \mathrm{nXn}+\text { et }
$$

Information:

$\mathrm{Y}=$ Dependent variable;

$\beta 0=$ Constant;

$\beta 1, \beta 2, \ldots \beta \mathrm{n}=$ Regression coefficient;

$\mathrm{X} 1, \mathrm{X} 2, \ldots \mathrm{Xn}=$ Independent variable;

et $=$ error term

Based on this equation, operationally the regression equation in this study is:

$$
\operatorname{LogTt}=\beta 0+\beta 1 \mathrm{rt}+\beta 2 \mathrm{Inft}+\text { et }
$$

Information:

$\mathrm{Tt}=$ Saving $(\mathrm{Y})$;

$\beta 0=$ Intercept (Constant);

b1, b2, b3, b4= Regression coefficient;

r (X1) = BI Rate, (X1);

$\operatorname{Inf}(\mathrm{X} 2)=$ Inflation, (X2);

et $=$ error term

The ARCH (p) model can be expressed in the following equation:

$$
\mathrm{Yt}=\beta 0+\beta 1 \mathrm{X} 1 \mathrm{t}+\mathrm{et}
$$

Information:

$\mathrm{Yt}=$ Dependent variable;

$\mathrm{X} 1 \mathrm{t}=$ independent variable;

$\beta 0=$ Intercept $($ Constant);

$\beta 1=$ Regression coefficient;

et $=$ error term

$$
\sigma 2 \mathrm{t}=\alpha 0+\alpha 1 \mathrm{e} 2 \mathrm{t}-1+\alpha 2 \mathrm{e} 2 \mathrm{t}-2+\ldots .+\alpha p e 2 \mathrm{t}-\mathrm{p}
$$

1. The fourth equation shows that the residual variety $(\sigma 2 t)$ has two elements: constant $(\alpha 0)$ and the residual square of the previous period (e2t-p).

2. The fifth equation is a linear model, the sixth equation is a non-linear model, so the OLS method cannot be used for model estimation. 
3. Can only be estimated using the Maximum Likelihood method.

The GARCH model (p, q) can be expressed in the following equation:

$$
\sigma 2 \mathrm{t}=\alpha 0+\alpha 1 \mathrm{e} 2 \mathrm{t}-1+\ldots+\underset{2 \mathrm{t}-\mathrm{q}}{\alpha \mathrm{ppe}-\mathrm{p}}+\lambda 1 \sigma 2 \mathrm{t}-1+\ldots+\underset{\text { (5) }}{\lambda \mathrm{q} \sigma}
$$

1. The equation shows the variety of residuals. To test the correctness of each variable $\sigma 2 t$ is not only influenced by the residual square of the previous period (e2t-p), but also by the variety of residuals in the previous period ( $\sigma 2 \mathrm{t}-\mathrm{q})$.

2. The GARCH model is like the ARCH model, also the estimation uses the Maximum Likelihood (ML) method.

In this study, the multiple regression equation becomes

$$
Y t=\beta 0+\beta 1 X 1 t+\beta 2 X 2 t+\ldots+\text { eit }
$$

Information:

$\mathrm{Yt}=$ Saving;

$\mathrm{X} 1 \mathrm{t}=\mathrm{BI}$ Rate;

$\mathrm{X} 2 \mathrm{t}=$ Inflation;

$\beta 0=$ Intercept $($ constant);

$\beta 1, \beta 2$, = Regression coefficient;

eit $=$ error term

To test the truth of each independent variable on the dependent variable, a hypothesis test was used, namely the simultaneous test ( $\mathrm{F}$ test) and partial test (t test). In addition to the simultaneous test and partial test, short-term and long-term testing is also carried out. The short-term test consists of the unit-root or stationarity test, $\mathrm{ARCH} / \mathrm{GARCH}$ and the classical assumption test. While the test carried out in the long term is the cointegration test.

ARCH and GARCH models are used to determine the effect of one or more independent variables on the dependent variable. The use of $\mathrm{ARCH}$ and $\mathrm{GARCH}$ models in this study is due to the fact that the independent and dependent variables change from time to time or have a volatility phenomenon, so the Ordinary Least Square (OLS) model cannot be implemented because the OLS model must be constant from time to time. If the residuals are not constant, then there is a heteroscedasticity problem so that the resulting coefficient is not Best Linear Unbiased Estimator (BLUE) and by using the maximum likelihood method, with the ARCH and GARCH models. The other tests used were Stationarity Test and Cointegration Test. To test whether the data used in this study are stationary or not, this study uses the Augmented Dickey-Fuller (ADF) test. The cointegration test is a long-term relationship between variables which although individually are not stationary, but a linear combination between these variables can be stationary. In general, it can be said that if the time series data $\mathrm{Y}$ and $\mathrm{X}$ are not stationary at the level but become stationary at the same difference, namely $\mathrm{Y}$ is $\mathrm{I}(\mathrm{d})$ and $\mathrm{X}$ is $\mathrm{I}(\mathrm{d})$ where $\mathrm{d}$ is the same level of differentiation, then the two data are cointegrated. In other words, the cointegration test can only be done when the data used in the research are integrated to the same degree [10-12].

\section{Results}

Table 1. Data Stationarity Test

\begin{tabular}{cccc}
\hline Variable & $\begin{array}{c}\text { Absolute } \\
\text { Value } \\
\text { Statistics } \\
\text { (ADF) }\end{array}$ & $\begin{array}{c}\text { Critical Value } \\
\text { Mackinnon } \\
\text { ADF (5\%) }\end{array}$ & Information \\
\hline Saving & -3.476727 & -3.544284 & Not Stationary \\
BI-Rate & -2.262027 & -3.529758 & Not Stationary \\
Inflation & -1.893828 & -3.544284 & Not Stationary \\
\hline
\end{tabular}

Furthermore, the three variables of Savings, BI-Rate, and Inflation that do not show stationarity at the level, then the data are tested for data stationarity at the first differentiation level with the results presented in Table 2 .

Table 2. Data Stationarity Test at the First Level

\begin{tabular}{cccc}
\hline Variable & $\begin{array}{c}\text { Absolute Value } \\
\text { Statistics (ADF) }\end{array}$ & $\begin{array}{c}\text { Critical Value } \\
\text { Mackinnon } \\
\text { ADF (5\%) }\end{array}$ & Information \\
\hline Saving & -4.191031 & -3.552973 & Stationary \\
BI-Rate & -4.876072 & -3.533083 & Stationary \\
Inflation & -5.245855 & -3.562882 & \\
\hline
\end{tabular}

Table 2 is the result of the data stationarity test at the first differentiation level. The results of the data stationarity test at the first differentiation level have shown that the Saving, BI-Rate, and Inflation variables are stationary assuming absolute data. The data can be said to be stationary if the calculated value of the ADF is greater than the critical value of the table ADF at a significant level of 0.05 . All the estimated variables are stationary, then it can be continued by conducting cointegration testing.

Table 3. Johansen Cointegration Test

\begin{tabular}{ccccc}
\hline Hypothesized & \multicolumn{5}{c}{ Trace } & 0.05 & \\
\hline No. of CE(s) & Eigenvalue & Statistic & $\begin{array}{c}\text { Critical } \\
\text { Value }\end{array}$ & Prob.** \\
\hline None $*$ & 0.815180 & 71.49731 & 29.79707 & 0.0000 \\
\hline At most 1 & 0.234939 & 10.71586 & 15.49471 & 0.2296 \\
\hline At most 2 & 0.029421 & 1.075063 & 3.841466 & 0.2998 \\
\hline Trace test indicates 1 cointegrating eqn(s) & at the 0.05 level \\
\hline Hypothesized & & Max-Eigen & 0.05 & \\
\hline No. of CE(s) & Eigenvalue & Statistic & $\begin{array}{c}\text { Critical } \\
\text { Value }\end{array}$ & Prob.** \\
\hline None * & 0.815180 & 60.78145 & 21.13162 & 0.0000 \\
\hline At most 1 & 0.234939 & 9.640798 & 14.26460 & 0.2366 \\
\hline At most 2 & 0.029421 & 1.075063 & 3.841466 & 0.2998 \\
\hline
\end{tabular}


Table 3 showed that there is 1 cointegrated at $\alpha=0.05$ among the research variables, this can be seen by the value of Trace Statistics $>$ Critical Value or 71.49731> 29.79707 with a probability of 0.0000 . Meanwhile, seen from the value of the Max-Eigen Statistic, there is 1 cointegrated, this can be seen from the Max-Eigen Statistics $>$ Critical Value or $60.78145>21.13162$ with a probability of 0.0000 . The conclusion based on the Trace Statistic and Max-Eigen Statistics test shows that there is 1 cointegration at a significant level of $\alpha=0.05$, which means that there is a long-term relationship between savings and its determining variables.

Table 4 shows the estimation results using the ARCH 1 model, when viewed from the $\mathrm{R}^{2}$ value of 0.910558 , then the model has a fairly large $\mathrm{R}^{2}$. Judging from the AIC criteria of -0.300892 and SIC of -0.044959 which is low. When viewed from the level of significance, only one variable, namely the BI-Rate for savings, is significant at $\alpha=0.05$, while inflation is not significant at $\alpha=0.05$ for savings. When viewed from the DW statistical value of 2.160545, which means there is no autocorrelation in the estimation results. With the ARCH 1 model equation as follows:

$$
\begin{array}{r}
\mathrm{T}=9.196914-0.118220 \mathrm{BI}-\mathrm{Rate}+0.005840 \mathrm{Inf}+ \\
0.802620 \mathrm{AR}(1)+\mathrm{e}
\end{array}
$$

Hypothesis testing results showed that based on the estimation results it is known that the F-count is 67,19085 with a probability of 0.0000 with $\alpha=0.05$, this shows that the BI-Rate and inflation variables together are able to provide a significant explanation of the savings variable with a $95 \%$ confidence level.
Regarding BI Rate, based on the estimation results obtained, the t-value is - (2.041716) with a probability of 0.0412 at $\alpha=0.05$. These results indicate that the BI-Rate has an effect and is significant on savings with a confidence level of $95 \%$ and the $t$-count is negative, so it can be stated that the BI-Rate has a negative and significant effect on savings.

In term of inflation, based on the estimation results, the $\mathrm{t}$-count value is $(0.175483)$ with a probability of 0.8607 at $\alpha=0.05$. These results state that inflation has no and insignificant effect on savings with a confidence level of $95 \%$ and the t-count is positive, so it can be stated that inflation has no and significant effect on savings.

Lastly, the calculation of coefficient of determination, based on the estimation results, the coefficient of determination $\left(\mathrm{R}^{2}\right)$ is 0.910558 or $91.06 \%$. This shows that overall variations that occur in the independent variables (BI-Rate and Inflation) can explain the dependent variable (savings) of $91.06 \%$, while the remaining $8.94 \%$ is explained by other variables outside the model.

\section{Discussion}

Based on the estimation results obtained, the t-value is (2.041716) with a probability of 0.0412 at $\alpha=0.05$. These results indicate that the BI-Rate has an effect and is significant on savings with a confidence level of $95 \%$ and the t-count is negative, so it can be stated that the BI-Rate has a negative and significant effect on savings.

\begin{tabular}{|c|c|c|c|c|}
\hline & Coefficient & Std. Error & z-Statistic & Prob. \\
\hline $\mathrm{C}$ & 9.196914 & 0.612443 & 15.01677 & 0.0000 \\
\hline BI_RATE & -0.118220 & 0.057902 & -2.041716 & 0.0412 \\
\hline INFLATION & 0.005840 & 0.033277 & 0.175483 & 0.8607 \\
\hline $\operatorname{AR}(1)$ & 0.802620 & 0.255725 & 3.138609 & 0.0017 \\
\hline \multicolumn{5}{|c|}{ Variance Equation } \\
\hline $\mathrm{C}$ & 0.055516 & 0.020897 & 2.656634 & 0.0079 \\
\hline $\operatorname{RESID}(-1)^{\wedge} 2$ & 0.032824 & 0.029973 & 1.095148 & 0.2735 \\
\hline R-squared & 0.910558 & \multicolumn{2}{|c|}{ Mean dependent var } & 8.178195 \\
\hline Adjusted R-squared & 0.897006 & \multicolumn{2}{|c|}{ S.D. dependent var } & 0.526515 \\
\hline S.E. of regression & 0.168973 & \multicolumn{2}{|c|}{ Akaike info criterion } & -0.300892 \\
\hline Sum squared resid & 0.942207 & \multicolumn{2}{|c|}{ Schwarz criterion } & -0.044959 \\
\hline Log likelihood & 11.86738 & \multicolumn{2}{|c|}{ Hannan-Quinn criter. } & -0.209065 \\
\hline F-statistic & 67.19085 & \multicolumn{2}{|c|}{ Durbin-Watson stat } & 2.160545 \\
\hline Prob(F-statistic) & 0.000000 & & & \\
\hline Inverted AR Roots & \multicolumn{3}{|c|}{.80} & \\
\hline
\end{tabular}

Table 4. ARCH Estimation Results 1 
Empirically, the effect of interest rates on savings in this study contradicts other theories and studies. In this case, when the $\mathrm{BI}$ rate is raised, the commercial bank can raise the savings or credit interest rates, however, the banking sector does not necessarily raise the savings or credit interest rates, all depending on bank policy because in this case it is related to competition between banks. When the bi rate increases and commercial banks raise savings interest rates, banks will be faced with the problem of increasing bank funds, so that to cover this, banks must increase credit interest rates which in turn will cause the risk of bad credit. Then if the BI rate is lowered, it should be followed by a reduction in savings and credit interest rates. If the BI rate is lowered, the bank will respond by lowering the credit interest rate in order to reduce the cost of funds borne by the bank from the savings interest rate. The monetary policy adopted by Bank Indonesia is determined by the determination of the ideal interest rate, namely one that can balance the benefits of interest rates between the banking sector and the public as customers, including parties from the business sector [13].

Regarding the effect of inflation on savings, based on the estimation results, the $t$-count value is $(0.175483)$ with a probability of 0.8607 at $\alpha=0.05$. These results state that inflation has no and insignificant effect on savings with a confidence level of $95 \%$ and the t-count is positive, so it is empirically stated that inflation has no significant effect on savings. This contradicts the theory that an increase in inflation should cause purchasing power to decline. The income previously allocated for savings will be used partially or completely for consumption purposes so that automatically the income set aside for savings is now used for consumption needs so that it will reduce the saving rate.

However, the results of the empirical test between inflation and savings in this study are in line with the research of Helvira [6], Nurulhidayat [7], Lengkong et al., [8], Klasjok et al., [9] which found that inflation does not have a significant effect on saving. As the inflation rate in Central Sulawesi from 2005 to 2014, it was in the range of 5 to $10 \%$, which is categorized as a type of moderate inflation, namely inflation characterized by a slow increase in prices. So that the increase in inflation that occurs does not make the public immediately withdraw their savings [14]. This indicates that people are able to adjust their economic conditions to fluctuations in inflation so that inflation has not had a significant effect on the economic conditions of the community.

\section{Conclusions}

The development of banking has an important role in supporting the economic growth of a country or region. Therefore, the development of banking in a country can be used as a measure of a country's economic progress. Central Sulawesi, as one of the thirty-four developing provinces in Indonesia, is currently carrying out development in almost every region. The development process requires a large amount of financing. Central Sulawesi is currently active in the development process, both physical and non-physical. The development process is also inseparable from economic growth. To achieve economic growth, a large investment fund is required, one of which can be sourced from domestic savings. Public saving is one of the sources of financing in the context of domestic saving. In the context of long-term economic development and economic growth, attention to domestic savings is essential to maintain economic stability in Central Sulawesi.

Based on the results of the discussion on the hypothesis of the effect of the BI-Rate interest rate on savings, it can be concluded that the BI-rate variable has a negative and significant effect on the savings variable. Based on the results of the discussion on testing the hypothesis regarding the effect of the level of inflation on savings, it can be concluded that the inflation variable does not have a significant effect on the saving variable. An economy that continues to run with savings as one of the determining indicators in achieving economic success, therefore it is hoped that future researchers who will conduct research related to this research will enrich it by adding variables according to current economic conditions. In particular, this study underscores the findings regarding the negative effect of interest rates on savings in contradiction with the general economic theory of money. Therefore, as a bottom line, these findings are specifically applicable in the context of Central Sulawesi, Indonesia, in the years investigated. Therefore, further studies are expected to analyze the effect of interest rates more broadly and extend the years of investigation to support the fundamental economic theory of money. It also is suggested to develop a longer research period in some regions in Indonesia with the aim of getting even better results and using other dependent variables. 


\section{Appendix}

\section{Stationary Test}

1. Log Saving (Level)

Null Hypothesis: LOGSAVING has a unit root

Exogenous: Constant, Linear Trend

Lag Length: 4 (Automatic based on SIC, MAXLAG=11)

\begin{tabular}{|c|c|c|c|}
\hline & & t-Statistic & Prob.* \\
\hline \multicolumn{2}{|c|}{ Augmented Dickey-Fuller test statistic } & -3.476727 & 0.0577 \\
\hline Test critical values & $\begin{array}{c}1 \% \text { level } \\
5 \% \text { level } \\
10 \% \text { level }\end{array}$ & $\begin{array}{l}-4.243644 \\
-3.544284 \\
-3.204699\end{array}$ & \\
\hline
\end{tabular}

*MacKinnon (1996) one-sided p-values.

Augmented Dickey-Fuller Test Equation

Dependent Variable: D(LOGSAVING)

Method: Least Squares

Sample (adjusted): 2006Q2 2014Q4

Included observations: 35 after adjustments

\begin{tabular}{|c|c|c|c|c|}
\hline & Coefficient & Std. Error & $\mathrm{t}$-Statistic & Prob. \\
\hline LOGSAVING(-1) & -0.570290 & 0.164031 & -3.476727 & 0.0017 \\
\hline D(LOGSAVING(-1)) & 0.234357 & 0.174226 & 1.345131 & 0.1894 \\
\hline D(LOGSAVING(-2)) & 0.113503 & 0.146053 & 0.777140 & 0.4436 \\
\hline D(LOGSAVING(-3)) & -0.069148 & 0.126831 & -0.545202 & 0.5899 \\
\hline D(LOGSAVING(-4)) & 0.715120 & 0.109049 & 6.557771 & 0.0000 \\
\hline $\mathrm{C}$ & 4.157064 & 1.165745 & 3.566014 & 0.0013 \\
\hline @TREND(2005Q1) & 0.024494 & 0.007699 & 3.181612 & 0.0036 \\
\hline R-squared & 0.887835 & \multicolumn{2}{|c|}{ Mean dependent var } & 0.048588 \\
\hline Adjusted R-squared & 0.863800 & \multicolumn{2}{|c|}{ S.D. dependent var } & 0.122894 \\
\hline S.E. of regression & 0.045354 & \multicolumn{2}{|c|}{ Akaike info criterion } & -3.171764 \\
\hline Sum squared resid & 0.057597 & \multicolumn{2}{|c|}{ Schwarz criterion } & -2.860695 \\
\hline Log likelihood & 62.50588 & \multicolumn{2}{|c|}{ Hannan-Quinn criter. } & -3.064383 \\
\hline F-statistic & 36.93875 & \multicolumn{2}{|c|}{ Durbin-Watson stat } & 1.928336 \\
\hline Prob(F-statistic) & 0.000000 & & & \\
\hline
\end{tabular}

2. BI Rate (Level)

Null Hypothesis: BI_RATE has a unit root

Exogenous: Constant, Linear Trend

Lag Length: 0 (Automatic based on SIC, MAXLAG=11)

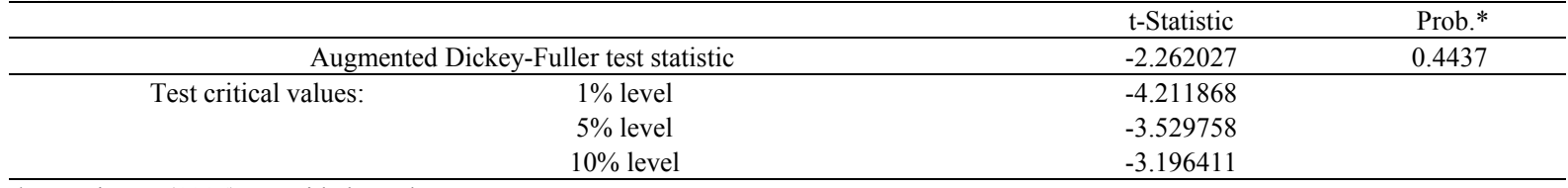

*MacKinnon (1996) one-sided p-values.

Augmented Dickey-Fuller Test Equation

Dependent Variable: D(BI_RATE)

Method: Least Squares

Sample (adjusted): 2005Q2 2014Q4

Included observations: 39 after adjustments

\begin{tabular}{|c|c|c|c|c|}
\hline & Coefficient & Std. Error & t-Statistic & Prob. \\
\hline BI_RATE(-1) & -0.226282 & 0.100035 & -2.262027 & 0.0298 \\
\hline $\mathrm{C}$ & 2.344134 & 1.050088 & 2.232323 & 0.0319 \\
\hline @TREND(2005Q1) & -0.027731 & 0.016785 & -1.652142 & 0.1072 \\
\hline R-squared & 0.125504 & \multicolumn{2}{|c|}{ Mean dependent var } & 0.005128 \\
\hline Adjusted R-squared & 0.076921 & \multicolumn{2}{|c|}{ S.D. dependent var } & 0.926887 \\
\hline S.E. of regression & 0.890526 & \multicolumn{2}{|c|}{ Akaike info criterion } & 2.679794 \\
\hline Sum squared resid & 28.54929 & \multicolumn{2}{|c|}{ Schwarz criterion } & 2.807760 \\
\hline Log likelihood & -49.25598 & \multicolumn{2}{|c|}{ Hannan-Quinn criter. } & 2.725707 \\
\hline F-statistic & 2.583292 & \multicolumn{2}{|c|}{ Durbin-Watson stat } & 1.471991 \\
\hline Prob(F-statistic) & 0.089462 & & & \\
\hline
\end{tabular}


3. Inflation (Level)

Null Hypothesis: INFLATION has a unit root

Exogenous: Constant, Linear Trend

Lag Length: 4 (Automatic based on SIC, MAXLAG=11)

\begin{tabular}{|c|c|c|c|}
\hline & & $\mathrm{t}$-Statistic & Prob.* \\
\hline \multicolumn{2}{|c|}{ Augmented Dickey-Fuller test statistic } & -1.893828 & 0.6364 \\
\hline Test critical values: & $1 \%$ level & -4.243644 & \\
\hline & $5 \%$ level & -3.544284 & \\
\hline & $10 \%$ level & -3.204699 & \\
\hline
\end{tabular}

*MacKinnon (1996) one-sided p-values.

Augmented Dickey-Fuller Test Equation

Dependent Variable: D(INFLATION)

Method: Least Squares

Sample (adjusted): 2006Q2 2014Q4

Included observations: 35 after adjustments

\begin{tabular}{|c|c|c|c|c|}
\hline & Coefficient & Std. Error & t-Statistic & Prob. \\
\hline INFLATION(-1) & -0.422058 & 0.222860 & -1.893828 & 0.0686 \\
\hline D(INFLATION(-1)) & 0.043818 & 0.165298 & 0.265082 & 0.7929 \\
\hline D(INFLATION(-2)) & 0.321836 & 0.171678 & 1.874651 & 0.0713 \\
\hline D(INFLATION(-3)) & 0.252985 & 0.180873 & 1.398690 & 0.1729 \\
\hline D(INFLATION(-4)) & -0.454820 & 0.179582 & -2.532661 & 0.0172 \\
\hline $\mathrm{C}$ & 3.957372 & 3.044155 & 1.299990 & 0.2042 \\
\hline @ TREND(2005Q1) & -0.040741 & 0.062245 & -0.654524 & 0.5181 \\
\hline R-squared & 0.557556 & \multicolumn{2}{|c|}{ Mean dependent var } & -0.218571 \\
\hline Adjusted R-squared & 0.462747 & \multicolumn{2}{|c|}{ S.D. dependent var } & 2.795160 \\
\hline S.E. of regression & 2.048783 & \multicolumn{2}{|c|}{ Akaike info criterion } & 4.449226 \\
\hline Sum squared resid & 117.5304 & \multicolumn{2}{|c|}{ Schwarz criterion } & 4.760295 \\
\hline Log likelihood & -70.86145 & \multirow{2}{*}{\multicolumn{2}{|c|}{$\begin{array}{l}\text { Hannan-Quinn criter. } \\
\text { Durbin-Watson stat }\end{array}$}} & 4.556607 \\
\hline F-statistic & 5.880817 & & & 1.942165 \\
\hline Prob(F-statistic) & 0.000457 & \multicolumn{2}{|c|}{ Durbin-Watson stat } & \\
\hline
\end{tabular}

\section{Stationarity Test 1st Difference Level}

1. Log Saving

Null Hypothesis: D(LOGSAVING) has a unit root

Exogenous: Constant, Linear Trend

Lag Length: 5 (Automatic based on SIC, MAXLAG=11)

\begin{tabular}{|c|c|c|c|}
\hline & & t-Statistic & Prob.* \\
\hline \multicolumn{2}{|c|}{ Augmented Dickey-Fuller test statistic } & -4.191031 & 0.0119 \\
\hline Test critical values: & $1 \%$ level & -4.262735 & \\
\hline & $5 \%$ level & -3.552973 & \\
\hline & $10 \%$ level & -3.209642 & \\
\hline
\end{tabular}

*MacKinnon (1996) one-sided p-values.

Augmented Dickey-Fuller Test Equation

Dependent Variable: D(LOGSAVING,2)

Method: Least Squares

Sample (adjusted): 2006Q4 2014Q4

Included observations: 33 after adjustments

\begin{tabular}{|c|c|c|c|c|}
\hline & Coefficient & Std. Error & t-Statistic & Prob. \\
\hline D(LOGSAVING(-1)) & -2.099093 & 0.500854 & -4.191031 & 0.0003 \\
\hline D(LOGSAVING(-1),2) & 0.901329 & 0.426276 & 2.114427 & 0.0446 \\
\hline D(LOGSAVING(-2),2) & 0.730359 & 0.368937 & 1.979630 & 0.0589 \\
\hline D(LOGSAVING(-3),2) & 0.230742 & 0.274901 & 0.839363 & 0.4092 \\
\hline D(LOGSAVING(-4),2) & 0.663914 & 0.203713 & 3.259067 & 0.0032 \\
\hline D(LOGSAVING(-5),2) & 0.341173 & 0.160126 & 2.130659 & 0.0431 \\
\hline $\mathrm{C}$ & 0.142832 & 0.038867 & 3.674847 & 0.0011 \\
\hline @TREND(2005Q1) & -0.002125 & 0.000989 & -2.147677 & 0.0416 \\
\hline R-squared & 0.965141 & \multicolumn{2}{|c|}{ Mean dependent var } & 0.002589 \\
\hline Adjusted R-squared & 0.955381 & \multicolumn{2}{|c|}{ S.D. dependent var } & 0.226586 \\
\hline S.E. of regression & 0.047862 & \multicolumn{2}{|c|}{ Akaike info criterion } & -3.033763 \\
\hline Sum squared resid & 0.057270 & \multicolumn{2}{|c|}{ Schwarz criterion } & -2.670973 \\
\hline Log likelihood & 58.05709 & \multicolumn{2}{|c|}{ Hannan-Quinn criter. } & -2.911695 \\
\hline F-statistic & 98.88340 & \multirow{2}{*}{\multicolumn{2}{|c|}{ Durbin-Watson stat }} & 1.881318 \\
\hline Prob(F-statistic) & 0.000000 & & & \\
\hline
\end{tabular}




\section{BI Rate}

Null Hypothesis: D(BI_RATE) has a unit root

Exogenous: Constant, Linear Trend

Lag Length: 0 (Automatic based on SIC, MAXLAG=11)

\begin{tabular}{|c|c|c|c|}
\hline & & $\mathrm{t}$-Statistic & Prob.* \\
\hline \multicolumn{2}{|c|}{ Augmented Dickey-Fuller test statistic } & -4.876072 & 0.0018 \\
\hline \multirow[t]{3}{*}{ Test critical values: } & $1 \%$ level & -4.219126 & \\
\hline & $5 \%$ level & -3.533083 & \\
\hline & $10 \%$ level & -3.198312 & \\
\hline
\end{tabular}

*MacKinnon (1996) one-sided p-values.

Augmented Dickey-Fuller Test Equation

Dependent Variable: D(BI_RATE,2)

Method: Least Squares

Sample (adjusted): 2005Q3 2014Q4

Included observations: 38 after adjustments

\begin{tabular}{|c|c|c|c|c|}
\hline & Coefficient & Std. Error & $\mathrm{t}$-Statistic & Prob. \\
\hline D(BI_RATE(-1)) & -0.805114 & 0.165115 & -4.876072 & 0.0000 \\
\hline $\mathrm{C}$ & -0.011182 & 0.324333 & -0.034477 & 0.9727 \\
\hline @TREND(2005Q1) & $5.30 \mathrm{E}-05$ & 0.013953 & 0.003797 & 0.9970 \\
\hline R-squared & 0.404971 & \multicolumn{2}{|c|}{ Mean dependent var } & -0.011579 \\
\hline Adjusted R-squared & 0.370969 & \multicolumn{2}{|c|}{ S.D. dependent var } & 1.188150 \\
\hline S.E. of regression & 0.942339 & \multicolumn{2}{|c|}{ Akaike info criterion } & 2.794753 \\
\hline Sum squared resid & 31.08009 & \multicolumn{2}{|c|}{ Schwarz criterion } & 2.924036 \\
\hline Log likelihood & -50.10031 & \multicolumn{2}{|c|}{ Hannan-Quinn criter. } & 2.840751 \\
\hline F-statistic & 11.91033 & \multicolumn{2}{|c|}{ Durbin-Watson stat } & 2.032768 \\
\hline $\operatorname{Prob}($ F-statistic $)$ & 0.000113 & & & \\
\hline
\end{tabular}

3. Inflation

Null Hypothesis: D(INFLATION) has a unit root

Exogenous: Constant, Linear Trend

Lag Length: 7 (Automatic based on SIC, MAXLAG=11)

\begin{tabular}{|c|c|c|c|}
\hline & & $\mathrm{t}$-Statistic & Prob.* \\
\hline \multicolumn{2}{|c|}{ Augmented Dickey-Fuller test statistic } & -5.245855 & 0.0009 \\
\hline Test critical values: & $1 \%$ level & -4.284580 & \\
\hline & $5 \%$ level & -3.562882 & \\
\hline & $10 \%$ level & -3.215267 & \\
\hline
\end{tabular}

*MacKinnon (1996) one-sided p-values.

Augmented Dickey-Fuller Test Equation

Dependent Variable: D(INFLATION,2)

Method: Least Squares

Sample (adjusted): 2007Q2 2014Q4

Included observations: 31 after adjustments

\begin{tabular}{|c|c|c|c|c|}
\hline & Coefficient & Std. Error & t-Statistic & Prob. \\
\hline D(INFLATION(-1)) & -4.603556 & 0.877561 & -5.245855 & 0.0000 \\
\hline D(INFLATION(-1),2) & 2.958710 & 0.753263 & 3.927857 & 0.0008 \\
\hline D(INFLATION(-2),2) & 2.666662 & 0.633730 & 4.207886 & 0.0004 \\
\hline D(INFLATION(-3),2) & 2.303349 & 0.536038 & 4.296991 & 0.0003 \\
\hline D(INFLATION(-4),2) & 1.426914 & 0.422015 & 3.381194 & 0.0028 \\
\hline D(INFLATION(-5),2) & 1.164122 & 0.332266 & 3.503583 & 0.0021 \\
\hline D(INFLATION(-6),2) & 0.876704 & 0.266676 & 3.287525 & 0.0035 \\
\hline D(INFLATION(-7),2) & 0.374380 & 0.177314 & 2.111399 & 0.0469 \\
\hline $\mathrm{C}$ & -3.570502 & 1.252303 & -2.851149 & 0.0096 \\
\hline @TREND(2005Q1) & 0.119135 & 0.045183 & 2.636746 & 0.0154 \\
\hline R-squared & 0.876589 & \multicolumn{2}{|c|}{ Mean dependent var } & 0.177419 \\
\hline Adjusted R-squared & 0.823699 & \multicolumn{2}{|c|}{ S.D. dependent var } & 4.068577 \\
\hline S.E. of regression & 1.708325 & \multicolumn{2}{|c|}{ Akaike info criterion } & 4.164600 \\
\hline Sum squared resid & 61.28584 & \multicolumn{2}{|c|}{ Schwarz criterion } & 4.627176 \\
\hline Log likelihood & -54.55130 & \multicolumn{2}{|c|}{ Hannan-Quinn criter. } & 4.315388 \\
\hline F-statistic & 16.57368 & \multicolumn{2}{|c|}{ Durbin-Watson stat } & 2.107414 \\
\hline $\operatorname{Prob}(\mathrm{F}$-statistic) & 0.000000 & & & \\
\hline
\end{tabular}




\section{Cointegration Test}

Sample (adjusted): 2006Q1 2014Q4

Included observations: 36 after adjustments

Trend assumption: Linear deterministic trend

Series: LOGSAVING BI_RATE INFLATION

Lags interval (in first differences): 1 to 3

Unrestricted Cointegration Rank Test (Trace)

\begin{tabular}{ccccc}
\hline Hypothesized & & Trace & 0.05 & \\
No. of CE(s) & Eigenvalue & Statistic & Critical Value & Prob.** \\
\hline None & 0.815180 & 71.49731 & 29.79707 & 0.0000 \\
At most 1 & 0.234939 & 10.71586 & 15.49471 & 0.2296 \\
At most 2 & 0.029421 & 1.075063 & 3.841466 & 0.2998 \\
\hline
\end{tabular}

Trace test indicates 1 cointegrating eqn(s) at the 0.05 level

* denotes rejection of the hypothesis at the 0.05 level

**MacKinnon-Haug-Michelis (1999) p-values

\begin{tabular}{ccccc}
\multicolumn{5}{c}{ Unrestricted Cointegration Rank Test (Maximum Eigenvalue) } \\
\hline Hypothesized & \multicolumn{1}{c}{ Max-Eigen } & 0.05 & \\
No. of CE(s) & Eigenvalue & Statistic & Critical Value & Prob.** \\
\hline None & 0.815180 & 60.78145 & 21.13162 & 0.0000 \\
At most 1 & 0.234939 & 9.640798 & 14.26460 & 0.2366 \\
At most 2 & 0.029421 & 1.075063 & 3.841466 & 0.2998 \\
\hline
\end{tabular}

Max-eigenvalue test indicates 1 cointegrating eqn(s) at the 0.05 level

* denotes rejection of the hypothesis at the 0.05 level

**MacKinnon-Haug-Michelis (1999) p-values

Unrestricted Cointegrating Coefficients (normalized by $\mathrm{b}^{\prime * \mathrm{~S}} 11 * \mathrm{~b}=\mathrm{I}$ ):

\begin{tabular}{|c|c|c|c|}
\hline LOGSAVING & BI_RATE & INFLATION & \\
\hline 0.884320 & -1.364967 & 0.972897 & \\
\hline-0.604063 & -0.972529 & 0.136483 & \\
\hline-3.966939 & -1.094405 & 0.136367 & \\
\hline \multicolumn{4}{|c|}{ Unrestricted Adjustment Coefficients (alpha): } \\
\hline D(LOGSAVING) & -0.030101 & -0.017035 & 0.005774 \\
\hline D(BI_RATE) & -0.034134 & 0.278479 & 0.073662 \\
\hline D(INFLATION) & -1.874543 & 0.674436 & 0.001720 \\
\hline \multicolumn{2}{|c|}{1 Cointegrating Equation $(\mathrm{s}):$} & Log likelihood & -35.94285 \\
\hline \multicolumn{4}{|c|}{ Normalized cointegrating coefficients (standard error in parentheses) } \\
\hline LOGSAVING & BI_RATE & INFLATION & \\
\hline 1.000000 & $-1 . \overline{5} 43522$ & 1.100164 & \\
\hline & $(0.19222)$ & $(0.10663)$ & \\
\hline \multicolumn{4}{|c|}{ Adjustment coefficients (standard error in parentheses) } \\
\hline \multirow[t]{2}{*}{ D(LOGSAVING) } & -0.026619 & & \\
\hline & $(0.00897)$ & & \\
\hline \multirow[t]{2}{*}{ D(BI_RATE) } & -0.030186 & & \\
\hline & $(0.12690)$ & & \\
\hline \multirow[t]{2}{*}{ D(INFLATION) } & -1.657695 & & \\
\hline & $(0.29238)$ & & \\
\hline \multicolumn{2}{|c|}{2 Cointegrating Equation(s): } & Log likelihood & -31.12245 \\
\hline \multicolumn{4}{|c|}{ Normalized cointegrating coefficients (standard error in parentheses) } \\
\hline LOGSAVING & BI_RATE & INFLATION & \\
\hline 1.000000 & 0.000000 & 0.451084 & \\
\hline \multirow{3}{*}{0.000000} & & $(0.10016)$ & \\
\hline & 1.000000 & -0.420519 & \\
\hline & & $(0.06480)$ & \\
\hline \multicolumn{4}{|c|}{ Adjustment coefficients (standard error in parentheses) } \\
\hline \multirow[t]{2}{*}{ D(LOGSAVING) } & -0.016329 & 0.057653 & \\
\hline & $(0.01024)$ & $(0.01602)$ & \\
\hline \multirow[t]{2}{*}{ D(BI_RATE) } & -0.198405 & -0.224237 & \\
\hline & $(0.14163)$ & $(0.22164)$ & \\
\hline \multirow[t]{2}{*}{ D(INFLATION) } & -2.065097 & 1.902779 & \\
\hline & $(0.32328)$ & $(0.50592)$ & \\
\hline
\end{tabular}




\section{ARCH Estimation Results 1}

Dependent Variable: LOGSAVING

Method: ML - ARCH (Marquardt) - Normal distribution

Sample (adjusted): 2005Q2 2014Q4

Included observations: 39 after adjustments

Failure to improve Likelihood after 7 iterations

Presample variance: backcast (parameter $=0.7)$

$\mathrm{GARCH}=\mathrm{C}(5)+\mathrm{C}(6) * \operatorname{RESID}(-1)^{\wedge} 2$

\begin{tabular}{ccccc}
\hline & Coefficient & Std. Error & z-Statistic & Prob. \\
\hline C & 9.196914 & 0.612443 & 15.01677 & 0.0000 \\
BI_RATE & -0.118220 & 0.057902 & -2.041716 & 0.0412 \\
INFLATION & 0.005840 & 0.033277 & 0.175483 & 0.8607 \\
AR(1) & 0.802620 & 0.255725 & 3.138609 & 0.0017 \\
& \multicolumn{2}{c}{ Variance Equation } & 2.656634 & 0.0079 \\
C & 0.055516 & 0.020897 & 0.2735 \\
RESID(-1)^2 & 0.032824 & 0.029973 & 8.178195 \\
R-squared & 0.910558 & Mean dependent var & 0.526515 \\
Adjusted R-squared & 0.897006 & S.D. dependent var & -0.300892 \\
S.E. of regression & 0.168973 & Akaike info criterion & -0.044959 \\
Sum squared resid & 0.942207 & Schwarz criterion & -0.209065 \\
Log likelihood & 11.86738 & Hannan-Quinn criter. & 2.160545 \\
F-statistic & 67.19085 & Durbin-Watson stat & \\
Prob(F-statistic) & 0.000000 & . & \\
\hline Inverted AR Roots & & & \\
\hline
\end{tabular}

\section{Heteroskedasticity Test: ARCH}

\begin{tabular}{|c|c|c|c|c|}
\hline F-statistic & 0.488376 & \multicolumn{2}{|c|}{ Prob. F(1,36) } & 0.4891 \\
\hline Obs*R-squared & 0.508609 & \multicolumn{2}{|c|}{ Prob. Chi-Square(1) } & 0.4757 \\
\hline \multicolumn{5}{|l|}{ Test Equation: } \\
\hline \multicolumn{5}{|c|}{ Dependent Variable: WGT_RESID^2 } \\
\hline \multicolumn{5}{|l|}{ Method: Least Squares } \\
\hline \multicolumn{5}{|l|}{ Sample (adjusted): 2005Q3 2014Q4 } \\
\hline \multicolumn{5}{|c|}{ Included observations: 38 after adjustments } \\
\hline & Coefficient & Std. Error & t-Statistic & Prob. \\
\hline $\mathrm{C}$ & 0.482499 & 0.135202 & 3.568722 & 0.0010 \\
\hline WGT_RESID^2(-1) & -0.116038 & 0.166045 & -0.698839 & 0.4891 \\
\hline R-squared & 0.013384 & \multicolumn{2}{|c|}{ Mean dependent var } & 0.433534 \\
\hline Adjusted R-squared & -0.014022 & \multicolumn{2}{|c|}{ S.D. dependent var } & 0.707848 \\
\hline S.E. of regression & 0.712794 & \multicolumn{2}{|c|}{ Akaike info criterion } & 2.211946 \\
\hline Sum squared resid & 18.29069 & \multicolumn{2}{|c|}{ Schwarz criterion } & 2.298135 \\
\hline Log likelihood & -40.02698 & \multicolumn{2}{|c|}{ Hannan-Quinn criter. } & 2.242612 \\
\hline F-statistic & 0.488376 & \multicolumn{2}{|c|}{ Durbin-Watson stat } & 2.042877 \\
\hline Prob(F-statistic) & 0.489143 & & & \\
\hline
\end{tabular}




\section{REFERENCES}

[1] Bank Indonesia (BI), “Annual Report 2016,” Jakarta: Bank Indonesia, 2016.

[2] BPS-Statistics Indonesia, "Statistical Yearbook of Indonesia 2016," Jakarta: BPS-Statistics Indonesia, 2016.

[3] Fetrian R, Herianingrum S, "Effect of Profit Sharing, Inflation and Gross Domestic Product (GDP) to the Third Party Funds of Islamic Banking in Indonesia," Aducational Research International, vol. 6, no. 2, pp. 66-74, 2017.

[4] Darmawan A, "Influence of Loan Interest Rate, Non-Performing Loan, Third Party Fund and Inflation Rate towards Micro, Small and Medium Enterprises (MSME) Credit Lending Distribution at Commercial Banks in Indonesia," In 2018 3rd International Conference on Education, Sports, Arts and Management Engineering (ICESAME 2018), July 2018. Atlantis Press.

[5] Sasongko G, Huruta AD, "Monetary policy and the causality between inflation and money supply in Indonesia," Business: Theory and Practice, no. 19, pp. 80-7, 2018.

[6] Helvira R, "Pengaruh PDRB Perkapita, Tingkat Suku Bunga Tabungan Bank Umum dan Inflasi terhadap Simpanan Masyarakat pada Bank Syariah di Kalimantan Barat," Jurnal Ekonomi Daerah (JEDA), vol. 1, no. 1, 2013.

[7] Nurulhidayat S, "Analisis faktor-faktor yang

mempengaruhi jumlah deposito mudharabah pada Bank Syariah Mandiri," Undergraduate thesis. Faculty of Economics and Business, University of Lampung, 2014.

[8] Lengkong NL, Rumate VA, Engka DS, "Pengaruh PDRB, Inflasi Dan Suku Bunga Terhadap Tingkat Tabungan Masyarakat Pada Bank Sulutgo." Jurnal Pembangunan Ekonomi Dan Keuangan Daerah, vol. 19, no. 5, pp. 1-4, 2019.

[9] Klasjok K, Rotinsulu TO, Maramis MT, “Analisis Faktor-Faktor Yang Mempengaruhi Tabungan Masyarakat Pada Bank Umum Di Papua Barat (Periode Tahun 2008-2017)," Jurnal Berkala Ilmiah Efisiensi, vol. 18, no. 3, 2018.

[10] Widarjono A, "Ekonometrika: teori dan aplikasi untuk ekonomi dan bisnis," Yogyakarta: Ekonisia, 2007.

[11] Baltagi B, "Econometric analysis of panel data," Hoboken: John Wiley \& Sons; 2008.

[12] Gujarati DN, Porter DC, Gunasekar S, "Basic econometrics," McGraw-Hill Education, 2012.

[13] Sinaga JS, Muda I, Silalahi AS, "The Effect of BI Rate, Exchange Rate, Inflation and Third Party Fund (DPK) on Credit Distribution and Its Impact on Non-Performing Loan (NPL) on XYZ Commercial Segment Bank, Universal Journal of Accounting and Finance, vol. 8, no. 3, pp. 55 - 64, 2020. DOI: 10.13189/ujaf.2020.080301

[14] Noreen A, Asif R, Nisar S, Qayyum N, "Model building and forecasting of bank credit to public and private sector," Universal Journal of Accounting and Finance, vol. 5, no. 4, 2017. DOI: $10.13189 /$ ujaf.2017.050401 